УДК $82.01 / 09$

\title{
Татьяна Марченко
}

\section{ИМАГОЛОГИЧЕСКИЕ АСПЕКТЫ НАУЧНОГО НАСЛЕДИЯ Л.Г. ФРИЗМАНА}

\section{Вступление}

Научное наследие профессора Л.Г. Фризмана обширно и многообразно. Всё им написанное - работы по истории жанра, труды, возвращающие в историю литературы несправедливо забытые имена и произведения, переосмысливающие историко-культурные эпохи - неизменно выдержано в лучших традициях академического литературоведения с его приверженностью историзму, точной литературной фактографии, интересу к личности автора, обилию материала, сопоставлениям и сравнениям. Используя многие эффективные наработки исторической поэтики, сравнительноисторического литературоведения, системно-функционального анализа, учёный сознательно избегал новомодной терминологии, методологических исканий семиотики, структурализма, постструктурализма, деструктурализма, нарратологии с их демонстративной заменой Произведения на Текст, «смертью автора», исключением историзма и т.д.

Ивсёжеприверженность филологическимтрадициямнепомешала его трудам оставаться глубоко современными и актуальными. Примером тому - книга «Такая судьба. Еврейская тема в русской литературе», которая вышла в харьковском издательстве «Фолио» в 2015 году. Учёный ни разу не воспользовался термином «имагология», но, по сути, замысел и его реализация - проанализировать ментальные представления русских писателей о евреях и еврействе, воссоздать процессы рецепции и функционирования в русском национальном сознании образов представителей «чужого» этноса, «иной» культуры обеспечили ей заметное место в ряду имагологических исследований.

(C) Татьяна Марченко, 2020

http://dx.doi.org/10.34142/2312-1076.2020.2.96.06 
92 Наукові записки ХНПУ ім. Г.С. Сковороди. Літературознавство, 2020, вип. 2(96)

Цель настоящей статьи - представить указанную книгу Л.Г. Фризмана как имагологически значимую, проанализировать специфику научно-популярного стиля и методологических подходов учёного к характеристике еврейской темы как сквозной в русской литературе XIX-XX вв.

\section{Методология и методы исследования}

Наша статья - исследование об исследовании - базируется на методологии, которую и Л.Г. Фризман, приверженец классического литературоведения, тем не менее, не мог не использовать наряду с традиционными для него подходами, следуя избранной им имагологической теме. Это когнитивно-дискурсивные методологии описания ианализа текстов, которые основываютсянапредставлениях о словесном творчестве как о ментальной деятельности и направлены на выявление связи между мыслью и её конкретным воплощением в художественной литературе, публицистике, эпистолярии, других парадигмах. Для нас принципиально значим тот факт, что этнообраз еврея, т.е. образ «другого», «иного», учёный анализирует не только как художественно-эстетический феномен (сфера исторической поэтики), но и в социально-идеологическом ракурсе. Русская словесность рассматривается учёным как сфера функционирования и, одновременно, как источник стереотипов, которые разными каналами транслируются в общественное сознание и формируют представления одного народа о другом.

Совершенно очевидно, что автор адресовал своё исследование широкой аудитории - открывая книгу, он обращается к читателю, надеясь не просто познакомить его с определённым кругом произведений и их героями, но «натолкнуть на размышления о более общих вещах, вплоть до исторических судеб русского еврейства» (Фризман, 2015: 4). Проведя необходимые изыскания, «отобрав круг нужных текстов, которые осмыслены по отдельности и в совокупности» (Фризман, 2015: 3), автор избежал и «намёка на занудное наукообразие», его текст свободен даже от библиографических ссылок, строго обязательных в академической 
практике. Именно поэтому мы намеренно исключили любые жанровые определения - объектом нашего анализа стала не монография, просто книга. Вышедшая далеко не в столичном издательстве, несмотря на скромный тираж, она удовлетворяла давно копившийся на постсоветском пространстве общественный интерес к «полузапретной», искажённой в силу идеологических причин теме культурным судьбам еврейства в Стране Советов. Стоит отметить, что первые систематизированные сведения о еврейской теме в русской советской литературе собраны в монографии А.В. Блюма «Еврейский вопрос под советской цензурой.1917-1991» (Блюм, 1996), которая, по сути, литературоведческим трудом в прямом смысле не является. Это, как свидетельствует название книги, цензурная история еврейских изданий и произведений писателейевреев, а также книг, посвящённых еврейству. Малодоступна широкой читательской аудитории и монография современного израильского слависта М.Я. Вайскопфа «Покрывало Моисея. Еврейская тема в эпоху романтизма» (Вайскопф, 2008).

Л.Г. Фризман избрал диахронический вектор исследования. Оперируя историко-литературным материалом, охватывающим два столетия, он не просто представил читателям динамику развития еврейской темы в её ментальной обусловленности, но воссоздал ещё один иноэтнокультурный текст русской литературы. Наряду с «малороссийским», «польским», «ливонским», «черкесским» и многими другими, он функционировал в художественном сознании нескольких поколений.

\section{Результаты и дискуссии}

Возникновение и развитие еврейской темы в русской литературе учёный рассматривает на фоне и с учётом широких исторических реалий, социологических, политических, психологических и социокультурных аспектов, повлиявших на развитие отношений русских и евреев в оппозиционных парадигмах «Свой»-«Чужой», «Я» - «Другой», «Мы» - «Они». Экспансионистская политика империи, присоединявшей территории, населённые евреями, 
черта оседлости, преимущественно им свойственный род занятий и образ жизни - это лишь некоторые, из приведенных в книге социальных факторов, которые повлияли на формирование присущих только евреям черт, характера и отношение к ним большей части населения. «Преобладало отношение не к данному еврею, а к еврею вообще, как представителю данной общности. Индивидуальные отличия и у разных людей, и в произведениях разных писателей, конечно, существовали, но это были скорее оттенки более или менее единого подхода», - пишет Л.Г. Фризман, по сути, делая вывод о стереотипности сформировавшегося отношения к живущему в России многомиллионному «народу без отечества» (Фризман, 2015: 5).

Стереотипно устойчивыми на протяжении XIX-XX вв. были настроения недоверия и настороженности по отношению к евреям, репрезентированные в русской литературе в великом множестве художественных текстов. Они базируются не на рационалистических доводах разума и логики, не на объективных фактах, а на эмоциональном подходе к еврейству. Эта субъективная эмоциональность убедительно показана автором книги именно как устоявшаяся традиция: «она проистекает, с одной стороны, из характерной для националистического сознания ксенофобии, a с другой - из религиозной вражды истового христианства к иудаизму» и человека своего времени» (Фризман, 2015: 30), «отношение к евреям Гоголя оригинальностью не отличалось, он разделяет то, которое в его время было общепринятым» (Фризман, 2015: 42), «автор “Ивана Выжигина" (т.е. Ф.В. Булгарин T.М.) шёл наравне с веком...» (Фризман, 2015: 53), именно эти и другие аналогичные утверждения учёного подводят читателей к выводу о существовании определённых закономерностей формирования собирательного образа еврейства в русской литературе.

Заявленная как объект исследования, еврейская тема в русской литературе складывается из множества составляющих - образов, ярких художественных портретов представителей нации, не имеющей своей земли, организованной по принципу status in statu - 
государство в государстве. Образы эти в подавляющем большинстве произведений являются второстепенными персонажами, но собранные и осмысленные в рамках одной книги, единого научного замысла они составляют имаготип, т.е. образ нации, который, в свою очередь, содержит контрастные имагемы - черты национального характера. Русские литераторы отразили как продукт коллективной общественной мысли следующий, ещё раз повторим - стереотипный взгляд на еврейский национальный характер: евреи корыстолюбивы и алчны, жадны и расчётливы, хитры и изворотливы. Но, в то же время, большая часть евреев умны и проницательны, верны своим верованиям и национальным устоям, ценят сделанное им добро, трудолюбивы и бережливы, чужды мотовства и пьянства. «Это качества, которые обывательское сознание привыкло считать еврейскими», - констатирует Л.Г. Фризман (Фризман, 2015: 31). Тщательно отобранными примерами он подтверждает, что у многих русских писателей еврейский национальный характер раскрывается многими сторонами и разнообразными качествами. Другое дело, что эти качества, прежде всего позитивные, не всегда и не сразу были увидены и восприняты большинством читателей, находившихся в плену по большей части негативных, эмоционально окрашенных стереотипов.

Ещё раз повторим, что особенностью любого стереотипа есть эмоциональная окрашенность - негативная или позитивная, а также долговечность, устойчивость. Долгое время представители еврейской нации, которых было много в коммерческой жизни России, были для русских писателей «как бы обязательным элементом её бытового пейзажа» (Фризман, 2015: 66), без ярко выраженных симпатий или неприязни (Д.В. Давыдов, Н.М. Коншин, В.Т. Нарежный, Р. Зотов, И.И. Лажечников, И.С. Тургенев, Ф.М. Решетников, А.П. Чехов). Однако примеров эмоционально окрашенного отношения к еврейству в истории русской литературы значительно больше. Так, Н.М. Гоголь, Ф.В. Булгарин, Н.В. Кукольник, Н.А. Некрасов, В.В. Крестовский, Ф.М. Достоевский, а в литературе XX века - 
В. Солоухин, А. Солженицын обозначили собственное, безусловно отрицательное отношение к еврейству.

Категория «стереотип», которой по отношению к еврейству оперирует Л.Г. Фризман, современными литературоведами всё чаще воспринимается как этностереотип, ибо охватывает сферы национальной ментальности, характера, коллективной системы ценностей, общий тип поведения. В свою очередь, категория «образ» по отношению к еврейским персонажам русских писателей воспринимается как этнообраз, ведь каждый из них представляет индивидуальные черты как этнически идентичные, характерные для целого народа.

Образ нации, «иной» по отношению к русскому большинству в громадной империи, становится для русских писателей неотъемлемой частью национальной картины мира. Его моделирование средствами художественного слова есть процесс мифотворческий, ведь, как отмечает А.С. Киченко, картина мира всегда в той или иной степени содержит семантический эквивалент мифа, структурную ситуацию мифа (Киченко, 2009: 10-11). Как неотъемлемая часть любой национальной картины мира миф отличается неконтролируемыми вариантами осмыслений (Киченко, 2009: 74). Это совершенно ясно показано в анализируемой нами книге. Л.Г. Фризман представил образ еврейства как продукт коллективного творчества великого множества литераторов, образ стереотипный и мифологизированный, проявляющий себя в конкретных произведениях в бесчисленных вариантах осмыслений. Причём исследовательская мысль учёного стремится систематизировать эти варианты.

Так, в книге приведены многочисленные случаи толкования еврейской темы в духе библейской мифологии. Вся пушкинская эпоха русской литературы, по сути, отождествляла понятия «еврейский» и «библейский». Мотив богом избранного, но гонимого народа, образы ветхозаветных персонажей, архетипные по природе своей библейские сюжеты пронизывают творчество литераторов, обращавшихся к еврейской теме на протяжении XIX-XX вв. 
Вполне понятна высокая частотность как прямого, так и аллюзивного обращения к библейскому материалу - подавляющее большинство русских литераторов не могли не признать экзистенциальность миссии еврейского народа в мировой истории. Но выше упомянутый тезис о неконтролируемых вариантах осмыслений мифа, в нашем случае мифа о еврействе, становится особенно интересным, когда учёный обращается к иллюстрации процессов зарождения и развития мифологии нового времени антисемитской, патриотически-юдофобской по своему содержанию.

Одним из наиболее распространённых вариантов нового мифа о еврействе в русской литературе стал тезис «евреи - хозяева жизни», основанный на философии всевластия еврейских денег. Его истоки в художественном творчестве Н.А. Некрасова (поэмы «Балет», «Современники», «Еврейская песня»). Нельзя не согласиться с утверждением автора исследования о том, что погоня за прибылями в середине XIX в. в России приобрела по преимуществу формы не здорового предпринимательства, но торгашества, которое и стало ассоциироваться с еврейством. Поэта тревожит новая тенденция подчинения русского общества власти «золотого тельца», под её влиянием рушатся вековые устои, уходят в прошлое моральные нормы. «Евреи вызывали у Некрасова страх, страх перед еврейским капиталом, приобретающим всё большее влияние и власть. Его страшит спайка еврейского мира, проникшего в его страну и насаждающего в ней чуждые ей нравы, традиции и вкусы», - пишет учёный (Фризман, 2015: 90).

Ещёодинвариантосмысленияэтогоантисемитскогомифаблестяще реконструирован на основе писем и статей «Дневника писателя» Ф.М. Достоевского. Для него евреи - виновники пореформенного разорения русского крестьянства и угнетатели, кровопийцы, «паразитирующие на девственно-неиспорченном русском народе» (цит. по Фризман, 2015: 127). Ограничительные законы против них способ самозащиты угнетённого большинства жителей огромной империи от разрушительного еврейского засилья. Рассматривая публицистику великого русского писателя как продукт его ментальной 
98 Наукові записки ХНПУ ім. Г.С. Сковороди. Літературознавство, 2020, вип. 2(96)

деятельности, Л.Г. Фризман приходит к выводу: «Антисемитизм Достоевского тесно связан со славянофильскими и панславистскими корнями его мировоззрения, с русским национально-религиозным мессианизмом, притязания которого приходили в неизбежное противоречие с мессианизмом еврейским» (Фризман, 2015: 98). Предпринятый анализ делает очевидным ещё один неприглядный для литературной репутации русского классика факт - во многом благодаря Ф.М. Достоевскому к концу 70-х годов XIX века слово «жид» перестало быть синоним слова «еврей» и приобрело иное, собственное значение, оскорбительное и унизительное для людей этой национальности.

Апогеем же мифа о всесилии евреев в России и даже их всемирном господстве стала откровенно погромная трилогия В.В. Крестовского «Тьма египетская», «Тамара Бендавид», «Торжество Ваала», которой в книге Л.Г. Фризмана тоже уделено надлежащее внимание как показательному звену в реализации еврейской темы русской литературы. Эпиграф трилогии «Жид идёт!» весьма показателен, он предваряет рассуждения писателя о «великой» миссии России противостоять еврейской экспансии.

Миф о мировом господстве евреев трансформировался у некоторых писателей в идею о губительном засилье евреев в русской литературе. В анализируемой нами книге воссозданы обстоятельства малоизвестной литературоведам скандальной полемики вокруг пьесы еврейского писателя Шолома Аша «С волной» (1909). После публичного чтения автором этой пьесы выступили Е. Чириков и К. Арабажин с заявлением о наплыве евреев в русскую литературу, что якобы искажает её национальное лицо. По поводу затронутой проблемы высказался и А.И. Куприн, правда сделал он это не публично, в письме редактору журнала «Мир Божий» Ф. Батюшкову, которое до наших дней хранится в Рукописном отделе Института русской литературы и опубликовано всего однажды - в израильском журнале «32». Ввиду недоступности этого эго-документа широкой читательской аудитории Л.Г. Фризман приводит из него довольно пространные выдержки. Становится очевидным, что крупнейший 
писатель своего времени, никогда публично не запятнавший себя антисемитизмом, призывавший оградить от преследований этот «великий, бездомный народ», в частной ситуации высказал мысль прямо противоположную - евреев не стоит допускать до литературного творчества на русском языке. «...Каждый еврей родится на свет Божий с предначертанной миссией быть русским писателем <..> Ради Бога, избранный народ! Идите в генералы, инженеры, учёные, доктора, адвокаты - куда хотите! Но не трогайте нашего языка, который вам чужд и который даже от нас, вскормленных им, требует теперь самого нежного, самого бережного и любовного отношения» (цит. по Фризман, 2015: 183).

Отдельной страницей в истории русского государственного антисемитизма и новых мифов о еврействе стали резонансные в обществе истории ритуальных убийств, в которых, как правило, обвиняли иудеев. Л.Г. Фризман показал, что русская литература прямо или косвенно откликалась на эти постыдные события (аллюзивные параллели с «велижским делом» у М.Ю. Лермонтова, отражение «саратовского дела» в неоконченном романе Д. Мордовцева «Профессор Ратмиров», оценка С. Надсоном «кутаисского дела» и, наконец «дело Бейлиса» и позиция В.Г. Короленко).

Мифологические, антисемитские по сути вариации на тему о роли еврейства в русской истории и их литературные воплощения у конкретных авторов и в конкретных произведениях, Л.Г. Фризман собрал и описал с полнотой, максимально возможной для избранного им исследовательского формата. Он довёл свои систематизированные наблюдения до советских времён, когда обвинения в адрес еврейства приняли не просто уродливые, но абсурдно-смешные формы. Как сатирически высказался В.С. Высоцкий, именно евреи «замучили слона в зоопарке» и украли весь хлеб урожая минувшего года (цит. по Фризман, 2015: 406).

Евреи и история русской революции - вот ещё один важный мифологизированный аспект еврейской темы, отразившийся в русской литературе во второй половине XIX - первой четверти XX в. Предвестниками этого варианта в осмыслении исторических 
100 Наукові записки ХНПУ ім. Г.С. Сковороди. Літературознавство, 2020, вип. 2(96)

судеб этого народа звучат многочисленные рассуждения Ф.М. Достоевского об опасности образованных евреев как носителей начал космополитизма, либерализма и социализма с ужасающей быстротой распространяющихся в народных массах. Наиболее полно и ярко тема еврейства как движущей силы русской революции раскроется в романах С.M. Степняка-Кравчинского «Андрей Кожухов» и В. Ропшина (литературный псевдоним Б. Савинкова) «То, чего не было».

Познавательная значимость книги «Такая судьба...» для широкой читательской аудитории усиливается в связи с наличием в ней информации о расстановке сил и позициях, занимаемых не только мастерами художественного слова, но и журналистами, крупнейшими издателями и органами печати относительно еврейства. Так, крупнейшим русским газетам «Московский вестник» М. Каткова и «Новое время» А. Суворина, находившихся на явно антисемитских позициях, идейно противостояли «проеврейские» ежемесячник «Восход» (редактор А.Е. Ландау), киевская газета «Заря» (редактор М.И. Кулишер), журнал «Наблюдатель» и другие издания. В советское время «славянофилы» и «почвенники» нового поколения группировались вокруг газет «День», «Московский литератор», «Советская Россия», журналов «Молодая гвардия», «Наш современник», «Москва». «Под видом национально-религиозного возрождения они проповедовали самый беззастенчивый шовинизм, окрашенный в расистские тона <..> публицисты этих изданий много писали о целенаправленном уничтожении русской культуры сионистами», констатирует Л.Г. Фризман (Фризман, 2015: 424).

Немало страниц в анализируемой нами книге посвящено роли русских писателей не только в трансляции и закреплении в массовом сознании «еврейских стереотипов», но и в их постепенном преодолении. Стихотворение современника Ф.М. Достоевского Л.А. Мея «Жиды, жиды! Как дико это слово!...» (1860) знаменовало начало новой тенденции, в полной мере реализованной русскими литераторамивХХв.-тенденциипреодоленияложнопатриотических, 
ксенофобских стереотипов. Выдающееся место в этом процессе учёный совершенно справедливо отводитпублицистике Н.С. Лескова. Н.Е. Салтыкова-Щедрина, В.Г. Короленко, М. Горького в которой ненависть к евреям названа «наследственным грехом русского народа, порождением его истории и психологии, <..> а их бесправие концентрированным выражением социального и морального зла, царившего в России» (цит. по Фризман, 2015: 217). Не без влияния публицистов в художественных текстах писателей рубежа веков растёт количество еврейских персонажей, написанных с явным авторским сочувствием (Н.Г. Гарин-Михайловский, К.М. Станюкович, А.И. Куприн).

Продолжая гуманистическую традицию, много и страстно о юдофобах и антисемитах уже советского толка писали Саша Чёрный и М. Горький, И. Эренбург и Е. Евтушенко, Н. Коржавин и Б. Чичибабин.

Особое внимание автор исследования уделил русским литераторам, которые корнями своими связаны с еврейством и сложно и мучительно переживали эту свою сопричастность (С. Надсон, Э. Багрицкий, И. Бабель, М. Алигер, И. Эренбург, Б. Слуцкий, Л. Лосев, И. Бродский). Всех их сближает гордость за свой народ, восхищение еврейской историей, стойкостью, с которой еврейство выносит все выпавшие тяготы и страдания. Ощущение своего еврейства для большинства из них не противоречило органической принадлежности русской культуре, в их творческом мире это отношения не оппозиционности, а соотнесённости.

\section{Выводы}

Аналитическое прочтениекнигипрофессора Л.Г. Фризмана «Такая судьба. Еврейская тема в русской литературе» с использованием методологических позитивов современных когнитивнодискурсивных практик не оставляет сомнений в её имагологической значимости. Собирательный образ еврейства, по сути, имаготип (образ нации) реконструирован в эстетическом и социальноидеологическом ракурсах, в разных дискурсивных парадигмах - 
102 Наукові записки ХНПУ ім. Г.С. Сковороди. Літературознавство, 2020, вип. 2(96)

художественной литературе, публицистике, эпистолярии, дневниковой прозе. Диахронический вектор исследования, избранный автором, подчеркнул сквозной и эволюционирующий характер еврейской темы в русской литературе XIX-XX вв.

Огромный текстовый массив, привлечённый автором книги к анализу, иллюстрирует одно из его основополагающих утвержденийотношение русских писателей «...к евреям было не просто неоднозначным, а насыщенным острыми противоречиями» (цит. по Фризман, 2015: с. 179). Это создание, а затем преодоление в силу ряда этносоциальных и этнопсихологических причин мифологизированных «еврейских» стереотипов. С точки зрения автора, эволюция еврейской темы в русской литературе XIX-XX вв. есть процесс наращивания всё новых и новых смыслов в трактовке судеб еврейского народа и оценках национальной сущности еврейства, его роли в жизни огромной державы на переломных этапах её развития.

Еврейская тема в русской литературе не была воссоздана Л.Г. Фризманом с исчерпывающей полнотой в плане охвата текстового материала, ею созданного. Это вряд ли возможно в рамках одной книги. Однако основные акценты в её изучении, веско расставленные авторитетным учёным, заложили прочную основу для всех последующих научных обращений к этой теме.

\section{Литература}

Блюм, А. Еврейский вопрос под советской цензурой. 1917-1991. СанктПетербург: Петербургский еврейский университет, 1996.

Вайскопф, М. Покрывало Моисея. Еврейская тема в эпоху романтизма. Москва-Иерусалим: Мосты и культуры, 2008.

Киченко, А.С. Творчество как мифотворчество: мифологическая составляющая художественного текста. Горловка: Изд-во ГГПИИЯ, 2009.

Фризман, Л.Г. Такая судьба. Еврейская тема в русской литературе. Харьков: Фолио, 2015. 


\section{References}

Blum, A. (1996). Yevrejsky Vopros pod Sovetskoy Tsenzuroy.1917-1991. ['Jewish Question' Under Soviet Censorship]. St Petersburg: Petersburg Yevrey University [in Russian].

Wiytskopf, M. (2008). Pokryvalo Moiseja. Yevrejskaya Tema v Epokhu Romantizma [The Veil of Moses. The Jewish Theme in the Romanticism Epoch]. Moskva-Yerusalim: Mosty i Cultury [in Russian].

Kitchenko, A. (2009). Tvorchestvo kak Mifotvorchestvo: Mifologicheskaya Sostavlyauschaya Hudozhestvennogo Teksta [Creation as Myth Creation: the Mythical Component of a Literary Text]. Gorlovka: GGPIIM [in Russian].

Frizman, L. (2015). Takaya sudba. Yevreyskaya Tema v Russkoy Literature [Fate. The Jewish Theme in Russian Literature]. Kharkov: Folio [in Russian].

\section{Анотація}

\section{T.М. Марченко. Імагологічні аспекти наукової спадщини Л.Г. Фрізмана}

Стаття присвячена аналізу імагологічного змісту книги Л.Г. Фрізмана «Така доля. Єврейська тема в російській літературі» i $\epsilon$ спробою осмислити внесок вченого в розвиток сучасної наукової проблематики, яка викликає інтерес у широкої аудиторії. Паралельно 3 використанням традицій, термінології та методології академічного літературознавства автор книги використав когнітивно-дискурсивні практики у вивченні величезного історико-літературного й художнього матеріалу. Особливості поєднання науковцем традиційних i сучасних наукових підходів розглянуті в пропонованій статті. Оскільки словесну творчість російських письменників представлено в книзі одночасно як естетичну і ментальну діяльність, акцентовано увагу на виявленні зв'язків між задумом та його конкретним втіленням в художній літературі, публіцистиці, епістолярії, інших парадигмах. Етнообраз єврея, тобто образ «іншого», вчений аналізує не тільки як художньо-естетичний феномен (сфера історичної поетики), але й в соціально-ідеологічному ракурсі. Російська словесність XIX$\mathrm{XX}$ ст. розглядається як сфера функціонування i, одночасно, як джерело стереотипів, які різними каналами транслюються в суспільну свідомість 
104 Наукові записки ХНПУ ім. Г.С. Сковороди. Літературознавство, 2020, вип. 2(96)

і формують уявлення одного народу про інший. В статті показано роль Л.Г. Фрізмана у вивченні соціальних та ідеологічних факторів, які зумовили літературне міфологізування «єврейських стереотипів» в російській масовій свідомості. Матеріал, що зібрав науковець, дозволяє відтворити картину того, як різні варіанти «єврейського міфу», які виникли в межах єврейської теми російської літератури, актуалізувались на певних історичних етапах, набували стереотипного характеру, а потім долались, змінювались іншими. Основні акценти, розставлені авторитетним вченим, започаткували міцну основу для всіх подальших наукових звернень до вивчення єврейської теми в російській літературі.

Ключові слова: імагологія, етнообраз, імаготип, стереотип, міф, національний характер.

\section{Аннотация}

\section{Т.М. Марченко. Имагологические аспекты научного наследия Л.Г. Фризмана}

Статья посвящена анализу имагологического содержания книги Л.Г. Фризмана «Такая судьба. Еврейская тема в русской литературе» и являет собой попытку осмыслить вклад учёного в развитие современной научной проблематики, вызывающей интерес у широкой аудитории. Наряду с использованием традиций, терминологии и методологии академического литературоведения автор книги применил когнитивнодискурсивные практики в изучении обширного историко-литературного и художественного материала. Особенности сочетания учёным традиционных и современных научных подходов рассмотрены в предлагаемой статье. Поскольку словесное творчество русских писателей представлено в книге одновременно как эстетическая и ментальная деятельность, акцентировано внимание на выявлении связей между замыслом и его конкретным воплощением в художественной литературе, публицистике, эпистолярии, других парадигмах. Этнообраз еврея, т.е. образ «другого», «иного», учёный анализирует не только как художественно-эстетический феномен (сфера исторической поэтики), но и в социально-идеологическом ракурсе. Русская словесность ХІХ-XX вв. рассматривается как сфера функционирования и, одновременно, как источник стереотипов, 
которые разными каналами транслируются в общественное сознание и формируют представления одного народа о другом. В статье показана роль Л.Г. Фризмана в изучении социальных и идеологических факторов, обусловивших литературное мифологизирование «еврейских стереотипов» в русском массовом сознании. Материал, собранный учёным, позволяет воссоздать картину того, как разные варианты «еврейского мифа», которые содержит еврейская тема русской литературы, актуализировались на определённых исторических этапах, приобретали стереотипный характер, а затем преодолевались, сменялись другими. Основные акценты, веско расставленные авторитетным учёным, заложили прочную основу для всех последующих научных обращений к изучению еврейской темы в русской литературе.

Ключевые слова: имагология, этнообраз, имаготип, стереотип, миф, национальный характер.

\section{Abstract \\ T.M. Marchenko. Imagological Aspects of L.G. Frizman's Scientific Heritage}

The research article analyzes the imagological content of L.G. Frizman's book 'Fate. The Jewish Theme in Russian Literature' and is an attempt to fully comprehend the scholar's contribution to the study of the issue which generates interest among many people. The author of the book used cognitive-discourse practices along with traditions, terms and methods of literary criticism in order to study a vast amount of historic and literary material. Frizman's ways of combining traditional and modern scientific approaches are given due attention in the article. Since Russian writers' work is presented in the book as both aesthetic and mental effort's result, we focus on the connections between the idea and its fulfillment in fiction and epistolary writing, opinion journalism, etc. Frizman analyzes the ethnoimage of a Jew, i.e. the image of "a stranger", not only as a literary-aesthetic phenomenon, which would be in the realm of historical poetry, but also from the social-ideological perspective. Russian literature of the $19^{\text {th }}$ and $20^{\text {th }}$ centuries is viewed as both a functioning system and a source of stereotypes which influence public perception and form a nation's opinion of another nation. This article reveals the role of L.G. Frizman in studying social and ideological 
factors which gave rise to literary mythologization of "Jewish stereotypes" in Russian mass consciousness. The materials gathered by the scholar allow us to see how different variations of the "Jewish myth", which appeared within the Jewish theme of Russian literature, became evident at certain points in history, how they turned into stereotypes, and eventually ended up broken and changed. The famous scientist's findings became the basis for further research in the Jewish theme in Russian literature.

Key words: imagology, ethnoimage, imagotype, stereotype, myth, national character.

Рукопис статті отримано 5 вересня 2020

Рукопис затверджено до публікащії 12 жовтня 2020

\section{Інформація про автора}

Марченко Тетяна Михайлівна - доктор філологічних наук, професор кафедри світової літератури, заступник директора з науково-педагогічної та навчально-методичної роботи Горлівського інституту іноземних мов ДВНЗ «Донбаський державний педагогічний університет»; вул. Василя Першина, 24, м. Бахмут Донецької обл., Україна, 84511; e-mail: tmarchenko2015@ukr. net; http:// orcid.org/0000-0001-6062-0517 